\title{
Effect of Supplementation Purslane (Portulaca Oleracea) as A Source of Alpha-Linolenic Acid on Production Performance and Physical Quality of Egg of Laying Hens
}

\author{
Lilik Retna Kartikasari", Adi Magna Patriadi Nuhriawangsa, Bayu Setya Hertanto and Winny Swastike \\ Department of Animal Science, Faculty of Agriculture, Sebelas Maret University, Jl. Ir. Sutami no 36A, Kentingan \\ Surakarta 57126, Central Java, Indonesia \\ *Corresponding author email: lilik_r_kartikasari@yahoo.com
}

\begin{abstract}
The aim of the study was to evaluate the effects of inclusion plant source of $n-3$ fat in the form of alpha-linolenic acid (ALA, 18:3n-3) on the diets of layers on production performance and physical quality of eggs. A total of $125 \mathrm{Hy}$-Line Brown hens (38 weeks old) were placed at individual cages and assigned to five dietary treatments. The dietary treatments were supplemented with $0,1.5,3.0,4.5$ and $6.0 \%$ purslane meal. Laying hens were fed for five weeks following a seven day adaptation period. Water and feed were provided ad libitum. Feed intake (FI) measured weekly and feed consumption ratio (FCR) was calculated at the end of the trial. A total of 25 egg yolk samples of day 35 ( $n=5$ egg yolks for each treatment) were collected to analyse physical quality of eggs. The data were analyzed using analysis of variance. Differences between treatment means were further analyzed using Duncan's New Multiple Range Test (DMRT). Results showed that the incorporation of plants rich in ALA did not modify FI, FCR, and egg production. Supplementation of purslane meal in the diets had no effect on physical quality of eggs, including egg weight, yolk weight, albumen index, yolk index and Haugh Unit (HU). The average of egg weight and yolk weight were 60,5 and $15.3 \mathrm{~g}$, respectively. Diet containing purslane meal increased yolk colour. In conclusion, laying hens that fed diet supplemented with purslane meal rich in ALA improved yolk colour and did not change the production performance of the laying hens or the qualities of the eggs.
\end{abstract}

Key words: Portulaca oleracea, alpha-linolenic acid, production performance, egg quality

Abstrak. Tujuan dari penelitian ini adalah mengetahui pengaruh lemak $n-3$ dari tanaman dalam bentuk alphalinolenic acid (ALA, 18:3n-3) pada pakan ayam petelur terhadap performa produksi dan kualitas fisik telur. 125 ayam Hy-Line Brown (38 minggu) ditempatkan pada kandang terpisah dan diberi 5 perlakuan pakan yang diberi tambahan $0,1,5,3,0,4,5$ dan 6,0\% tepung krokot. Ayam petelur diberi pakan selama 5 minggu dan 7 hari adaptasi. Pakan dan air diberikan ad libitum. Asupan pakan (FI) diukur setiap minggu dan rasio konsumsi pakan (FCR) dihitung pada akhir percobaan. Sejumlah 25 sample kuning telur pada hari ke 35 ( $n=5$ kuning telur dari setiap perlakuan) diambil untuk dianalusa kualitas fisiknya. Data dianalisa menggunakan Analysis of Variance (ANOVA). Perbedaan antara perlakuan kemudian dilanjutkan dengan Duncan's New Multiple Range Test (DMRT). Hasil penelitian menunjukkan bahwa suplemen tanaman kaya ALA pada pakan tidak mempengaruhi kualitas fisik telur, termasuk berat telur, berat kuning telur, indeks albumen, indeks kuning telur dan Haugh Unit (HU). Rataan berat telur dan berat kuning telur berturut-turut adalah 60.5 dan 15.3. Pakan mengandung tepung krokot meningkatkan warna kuning telur. Disimpulkan bahwa ayam petelur yang pakannya disuplementasi dengan tepung krokot yang kaya ALA meningkatkan warna kuning telur tetapi tidak mengubah performa produksi ayam telur atau kualitas telur.

Kata kunci: Portulaca oleracea, alpha-linolenic acid, performa produksi, kualitas telur

\section{Introduction}

Purslane provides a rich plant source of nutritional benefits (Sudhakar et al., 2010). Purslane is a green plant that is a source of many nutrients and contains many biologically active compounds, such as $\beta$-carotene, alpha- tocopherol, and ascorbic acid. Purslane is one of herbaceous weeds containing high level of omega-3 polyunsaturated fatty acids, alphalinolenic acid (n-3 PUFA, ALA, 18:3n-3), which is essential for normal human growth, health promotion, and disease prevention. Feeding laying hens with plant seeds or oils, rich in the 
n-3 PUFA, can be one of dietary approach to enhance $n-3$ fats in eggs. This strategy rests on the ability of laying hens to convert ALA to DHA. Some researchers reported that the $n-3$ fatty acid level of eggs increased by adding plant sources of n-3 PUFA (ALA), such as flax seed (Hayat et al., 2009), hemp seed (Gakhar et al., 2012) or chia seed (Ayerza, 2009). For example, the inclusion of $10 \%$ flaxseed ( 33\% ALA) in the diets of laying hens resulted in a higher accumulation of $n-3$ fatty acids than a control diet (Bean and Leeson, 2003). In addition, Kartikasari et al. (2014) reported that supplementation of flax seed oil enhanced the level of n-3 long chain polyunsaturated fatty acid ( $n-3$ LCPUFA), such as eicosapentaenoic acid (EPA) and docosahexaenoic acid (DHA), without reducing production performance.

While a number of studies reported the use of plant seeds, oil seeds or vegetable oils rich in ALA in $n-3$ fat content of eggs, there is little information in relation to the use of plant sources in performance parameters and egg quality. Some researchers found that the inclusion of high dietary levels of flaxseed $(10 \%)$ have been associated with a decrease in performance parameters such as reducing feed intake (Sari et al., 2002; Bean and Leeson, 2003), egg production (Sari et al., 2002), egg weight and yolk weight (Caston et al., 1994). However other investigators reported that the inclusion of dietary levels of purslane meal (2\%) increase egg weight and egg production (Aydin and Dogan, 2010). Therefore, the objectives of the current study included the evaluation of production performance and physical quality of eggs of laying hens fed diets supplemented with purslane meal, as a source of ALA.

\section{Materials and Method}

\section{General}

A total of $125 \mathrm{Hy}$-Line Brown hens (38 weeks old) were allocated at individual cages and assigned to five dietary treatments. Upon arrival, the hens were immediately weighed and housed one per cage ( $500 \mathrm{~mm}$ wide $\times 550$ $\mathrm{mm}$ deep $\times 500 \mathrm{~mm}$ high). The dietary treatments were the corn-soybean based diets containing crude protein $18 \%$ and energy 2,844 $\mathrm{kcal} / \mathrm{kg}$. The diets were supplemented with 0 , 1.5, 3.0, 4.5 and $6.0 \%$ Portulaca oleracea meal. Each of the five experimental treatments was replicated five times with five laying hens each. Laying hens were fed for five weeks following a seven day adaptation period. Water and feed were provided ad libitum for the duration of the experiment. During the first few days, the laying hens were observed at frequent intervals to ensure that they were comfortable with the environmental conditions and that all had access to adequate feed and water. The data of production performance were taken for a four week period. Feed consumption was measured weekly and FCR was calculated at the end of the trial ( $\mathrm{kg}$ feed $/ \mathrm{kg}$ egg). All hens were weighed individually at the beginning and at the end of the experimental period. A total of 25 egg yolk samples of day 35 ( $n=5$ egg yolks for each treatment) were collected to analyse physical quality of eggs.

Statistic. This experiment was based on a one-way classification design. The variable factor was varying levels of Portulaca oleracea meal, as a source of ALA in the diet. There were five diets comprised of a control diet and four experimental diets. The diets were a basal diet supplemented with $0,1.5,3.0,4.5$ and $6.0 \%$ Portulaca oleracea meal $(\mathrm{w} / \mathrm{w})$. The level of fat in the diets was held constant at approximately $3.5 \%$. The data were subject to analysis of variance (ANOVA). Differences between treatment means were further analysed using Duncan's New Multiple Range Test (DMRT) with significance level of $P<0.05$.

\section{Results and Discussion}

\section{Production performance}

Supplementation of dietary purslane meal did not significantly affect $(P>0.05)$ the production parameters measured including 
feed intake, feed conversion ratio, and egg production of laying hens (Table 1). It is known that supplemented purslane feed until $6 \%$ does not stimulate the function of pancreatic enzymes (lipases, amylases and proteases), and that some also increase the activity of digestive enzymes of gastric mucosa. Futhermore, purslane work to decrease enzyme activities in the current study was possibly due to the antioxidants in purslane which act against oxidative stress prevoiusly.

The average of hens feed intake fed on diets supplemented with purslane meal 0, 1.5, 3.0, 4.5, and 6.0\% was 100.16, 97.15, 100.47, 102.99, and $94.32 \mathrm{~g} /$ day, respectively. The average of feed conversion ratio of hens fed diets containing purslane meal was 2.11. Srinivasan (2005) states that It is known that most spices stimulate the function of pancreatic enzymes (lipases, amylases and proteases), and that some also increase the activity of digestive enzymes of gastric mucosa. Another researchers reported that the supplementation of high dietary levels of flaxseed $(10 \%)$ have been associated with decrease in performance parameters (Bean and Leeson, 2003). Importantly, under our condition, ALA enrichment by including purslane meal up to $6 \%$ did not adversely affect the performance parameters of laying hens. In addition, Evaris et al. (2015) found that the dietary inclusion of purslane meal (Portulaca oleracea) up to 200 $\mathrm{g} / \mathrm{kg}$ resulted in the increase in feed consumption, egg production and FCR. These results were similar to other findings on the effect of diets containing different fat sources including tallow, canola, sunflower, soybean and flaxseed oil on the performance of laying hens (Lelis et al., 2009; Ceylan et al., 2011). Kartikasari et al. (2012) reported that supplementation of vegetable oils rich in $n-3$ PUFA, such as canola oil and flaxseed oil, did not modify performance measurements including egg weight, egg production and FCR. The laying hens in all dietary treatment groups consumed a similar amount of feed throughout the trial, which suggests that there was no palatability problem or inhibitor effect such that reported when the diets were supplemented with high levels of flaxseed (Hayat et al., 2010). Furthermore, including purslane meal into the diets did not influence FCR, which is similar to the reports of previous studies in which ALA rich sources such as flaxseed (Hayat et al., 2009; Al-Nasser et al., 2011) or flaxseed oil (Mazalli et al., 2004; Kartikasari et al., 2014) were supplemented in the diet.

\section{Egg physical qualities}

Supplementing different levels of Portulaca oleracea meal had no significant $(P>0.05)$ effects on egg physical qualities including egg weight, yolk weight, yolk index, albumin index, and $\mathrm{HU}$ (Table 2). Diets containing purslane meal did not change egg weight $(60.6,59.7$, $63.3,60.8$, and 58.3 for $0,1.5,3.0,4.5$, and $6.0 \%$ purslane meal, respectively) and yolk weight $(14.9,15.5,15.6,15.3$, and 15.2 for 0 , 1.5, 3.0, 4.5, and $6.0 \%$ purslane meal, respectively). Physical quality of eggs are influenced by the feed consumption, methods

Table 1. Performance parameters of laying hens fed diets supplemented with Portulaca oleracea flour for 28 days

\begin{tabular}{lcccccc}
\hline Parameters & $0 \%$ & $1.5 \%$ & $3 \%$ & $4.5 \%$ & $6 \%$ & P value \\
\hline FC (g/ekor) & 100.16 & 97.15 & 100.47 & 102.99 & 94.32 & NS \\
FCR & 2.16 & 2.08 & 2.15 & 2.16 & 2.05 & NS \\
HDA (\%) & 59.20 & 54.97 & 54.40 & 51,89 & 54.17 & NS \\
\hline
\end{tabular}

$0 \%$ : Basal diet $+0 \%$ Portulaca oleraceae flour, $1.5 \%$ : basal diet $+1.5 \%$ Portulaca oleraceae flour, $3 \%$ : basal diet $+3 \%$ Portulaca oleraceae flour, $4.5 \%$ : basal diet $+4,5 \%$ Portulaca oleraceae flour and $6 \%$ : basal diet $+6 \%$ Portulaca oleraceae flour; NS= Not significant 
Table 2. Egg physical qualities of laying hens fed diets supplemented with purslane meal

\begin{tabular}{lcccccc}
\hline Parameters & P0 & P1 & P2 & P3 & P4 & P Value \\
\hline Egg weight $(\mathrm{g})$ & 60.62 & 59.72 & 63.27 & 60.82 & 58.30 & NS \\
Yolk weight $(\mathrm{g})$ & 14.94 & 15.51 & 15.60 & 15.31 & 15.22 & NS \\
Yolk colour & $8.80^{\mathrm{b}}$ & $8.82^{\mathrm{b}}$ & $8.80^{\mathrm{b}}$ & $9.00^{\mathrm{ab}}$ & $10.00^{\mathrm{a}}$ & $*$ \\
Yolk index & 3.95 & 3.74 & 3.78 & 3.92 & 3.87 & $\mathrm{NS}$ \\
Albumin index & 1.31 & 1.43 & 1.35 & 1.22 & 1.29 & $\mathrm{NS}$ \\
Haugh Unit & 93.16 & 98.92 & 96.79 & 91.78 & 95.60 & NS \\
\hline
\end{tabular}

P0: Basal diet + 0\% purslane meal, P1: basal diet + 1.5\% purslane meal, P2: basal diet + 3\% purslane meal, P3: basal diet + $4.5 \%$ purslane meal and P4: basal diet $+6 \%$ purslane meal; * significant; NS= not significant

of storage, the age of egg, texture shell, temperature and relative humidity during storage (Yuwanta, 2010). Some researchers reported that the inclusion of high dietary levels of flaxseed $(10 \%)$ caused a decrease in egg qualities, such as egg weight and yolk weight (Caston et al., 1994). In this current study, purslane tends to increase egg weight and yolk weight, yolk weight, yolk index, albumin index, and HU (Nobaht, 2014). Egg yolk color and egg weight by using purslane may be associated with the amount of feed intake, since by increasing the amount of purslane, the amount of feed intake increased thereby a higher amount of calcium was deposited in shell.

Purslane were not affected by the supplementation of dietary ALA, suggesting that the use of $6 \%$ purslane meal as a source of ALA can be applied without affecting physical egg quality. The absence of an effect on egg weight by high ALA diets is in accordance with the previous studies (Grobas et al., 2001; Hayat et al., 2009, Kartikasari et al., 2014), using purslane may be associated with the amount of feed intake (Nobakht, 2014). In addition, Evaris et al. (2015) reported that diets supplemented with $200 \mathrm{~g} / \mathrm{kg}$ purslane meal did not affect egg quality. Diet containing purslane increased yolk colour of eggs. The yolk color intensity of eggs from laying hens fed with purslane enriched diet probably resulted from the fact that purslane consumed by these hens were a source of xanthophylls for egg yolks (Krawczyk et al., 2011). In addition, purslane is rich in $\beta$ carotene so increasing the levels of purslane meal in the diets increased the amount of xanthophylls and vitamin A in the yolks, and this resulted in the increase in yolk color intensity. Using $6 \%$ of purslane in laying hens diets, may be the highest amounts of these carotenoids were transferred into egg yolk and elevated its color. Improve in yolk color density by using purslane medicinal plant is in agreement with previous observations (Rashed et al., 2004; Nobakht and Mehmannavaz, 2010; Sayedpiran et al. 2011; Nobakht and Mehmannavaz, 2013).

\section{Conclusions}

It was concluded that the dietary inclusion of Portulaca oleracea meal up to $6 \%$ can be applied without affecting production performance of laying hens and physical quality of the eggs.

\section{References}

Aydin R and I Dogan. 2010. Fatty acid profile and cholesterol content of egg yolk from chickens fed diets supplemented with purslane (Portulaca oleracea L.). J. Sci. Food Agric. 90(10):1759-1763.

Al-Nasser AY, AE Al-Saffar, FK Abdullah, ME AlBahouh, G Ragheb and MM Mashaly. 2011. Effect of adding flaxseed in the diet of laying hens on both production of omega- 3 enriched eggs and on production performance. Int. J. Poult. Sci. 10: 825-831.

Ayerza R. 2009. The seed's protein and oil content, fatty acid composition, and growing cycle length of a single genotype of chia (Salvia hispanica L .) as affected by environmental factors. J. Oleo Sci. 58: 347-354.

Bean LD and S Leeson. 2003. Long-term effects of feeding flaxseed on performance and egg fatty acid composition of brown and white hens. Poult. Sci. 82: 388-394. 
Cachaldora P, P Garcia-Rebollar, C Alvarez, JC De Blas and J Mendez. 2006. Effect of type and level of fish oil supplementation on yolk fat composition and $n-3$ fatty acids retention efficiency in laying hens. Br. Poult. Sci. 47: 43-49.

Caston LJ, EJ Squires and S Leeson. 1994. Hen performance, egg quality, and the sensory evaluation of eggs from SCWL hens fed dietary flax. Can. J. Anim. Sci. 74:347-353.

Ceylan N, I Ciftçi, C Mızrak, Z Kahraman and H Efil. 2011. Influence of different dietary oil sources on performance and fatty acid profile of egg yolk in laying hens. J. Anim. Feed Sci. 20:71-83.

Evaris E, LA Sarmiento-Franco, JC Segura-Correa, and CM Capetillo. 2015. Effect of dietary inclusion of purslane (portulaca oleracea I.) on yolk omega-3 fatty acids content, egg quality and productive performance of rhode island red hens. Trop. Subtrop. Agroec. 18:33-38.

Grobas S, J Mendez, R Lazaro, C de Blas and GG Mateo. 2001. Influence of source and percentage of fat added to diet on performance and fatty acid composition of egg yolks of two strains of laying hens. Poult. Sci. 80:1171-1179.

Gakhar N, E Goldber, M Jing, R Gibson, JD House. 2012. Effect of feeding hempseed and hempseed oil on laying hen performance and egg yolk fatty acid content: Evidence of their safety and efficacy for laying hen diets. Poult. Sci. 91:701711.

Hayat Z, G Cherian, TN Pasha, FM Khattak and MA Jabbar. 2009. Effect of feeding flax and two types of antioxidants on egg production, egg quality, and lipid composition of eggs. J. Appl. Poult. Res. 18: 541-551.

Hayat Z, G Cherian, TN Pasha, FM Khattak and MA Jabbar. 2010. Sensory evaluation and consumer acceptance of eggs from hens fed flax seed and 2 different antioxidants. Poult. Sci. 89:2293-2298.

Kartikasari LR, RJ Hughes, MS Geier, SEP Bastian and M Makrides, RA Gibson. 2012. Comparison of omega-3 levels in two strains of broilers and layers fed high alpha linolenic acid diets. In: Proceedings of the World's Poultry Science Association, the 23rd Annual Australian Poultry Science Symposium. Sydney. pp. 237-240.

Kartikasari LR, RJ Hughes, MS Geier, SEP Bastian and $M$ Makrides, RA Gibson. 2014. Optimizing the $n-3$ fatty acid content of eggs produced by layer hens fed with alpha-linolenic acid enriched diets while maintaining sensory qualities. In: Proceeding of the 16th Asian-Australasian Association of Animal Production Societies Congress. Yogyakarta, Indonesia. pp. 342-345.

Krawczyk J, Z Sokołowicz and B Szymczyk. 2011. Effect of housing system on cholesterol, vitamin and fatty acid content of yolk and physical characteristics of eggs from Polish native hens. Arch.Geflügelk. 75(3) S:151-157.
Lawlor JB, N Gaudette, T Dickson and JD House. 2010. Fatty acid profile and sensory characteristics of table eggs from laying hens fed diets containing microencapsulated fish oil. Anim. Feed Sci. Tech. 156:97-103.

Lelis G, MD Silva, FC Tavernari, L Albino and H Rostagno. 2009. Performance of layers fed diets containing different oils. Rev. Bras. Cienc. Avic. 11:235-240.

Mazalli MR, DE Faria, D Salvador and DT Ito. 2004. A comparison of the feeding value of different sources of fat for laying hens. 2. Lipid, cholesterol, and vitamin E profiles of egg yolk. J. Appl. Poult. Res. 13:280-290.

Nobakht A. 2014. The Effects of Different Levels of Portulaca oleracea, Medicinal Plant, on Performance, Egg Quality, Blood Biochemical and Immunity Parameters of Mature Laying Hens. Iranian J. Applied Animal Sci. 4(2):393-397

Nobakht $A$ and $Y$ Mehmannavaz. 2010. Investigation the effects of using of Thymus vulgaris, Lamiaceae menthapiperita, Oreganum valgare medicinal plants on performance, egg quality, blood and immunity parameters of laying hens. Iranian J. Anim. Sci. 41:129-136.

Nobakht $A$ and $Y$ Mehmannavaz. 2013. The effects different levels of nettle medicinal plant on performance, egg traits and blood biochemical and immunity cells of laying hens. Res. J. Anim. Sci. 22:35-45.

Rashed AN, FU Afifi, M Shaedah and M Taha. 2004. Investigation of the active constituents of Portulaca oleracea L. (Portulacaceae) growing in Jordan. Pak J Pharm Sci. 17:37-45.

Sari M, M Aksit, M Ozdogan and $\mathrm{H}$ Basmacioglu. 2002. Effects of addition of flaxseed to diets of laying hens on some production characteristics, levels of yolk and serum cholesterol, and fatty acid compositions of yolk. Arch. Geflugelkd. 66: 75-79.

Sayedpiran SA, A Nobakht and S Khodaei. 2011. The effects of using of probiotic, organic acid and blends of some medici nal herbs on performance, egg quality, blood biochemical and immunity parameters of laying hens. Tabriz Islamic Azad. Univ. Vet. J. 5:1111-1122.

Srinivasan K. 2005. Spices as influencers of body metabolism: an overview of three decades of research. Food Res. Int. 38:77-86.

Sudhakar D, RK Kishore, PR Parthasarathy. 2010. Portulaca oleracea L. extract ameliorates the cisplatin-induced toxic ity in chick embryonic liver. Indian J. Biochem. Biophys., 47:185-189.

Yuwanta T. 2010. Eggs and Egg Quality. Gadjah Mada University Press, Yogyakarta 